\title{
Abdülmecid Dönemi Hürriyet Bağlayıcı ve Kısıtlayıcı Ceza Uygulamalarına Dair Bir İnceleme
}

\author{
Dr. Öğr. Üyesi Özlem Poyraz \\ Kırşehir Ahi Evran Üniversitesi, Fen Edebiyat Fakültesi \\ Tarih Bölümü \\ ozlemsahin38@gmail.com
}

\begin{abstract}
Öz
Tanzimat dönemi ile birlikte hukuk alanında köklü ve ciddi adımların atıldığ bilinmektedir. Yeni yasal düzenlemelerin hukuk camiası içinde yer bulması ve kullanılmaya başlanması bu adımların sadece birkaçını oluşturmuştur. Bu araştırmanın amacı, ceza kanunnamelerindeki ağır cezalar kategorisinde yer alan hürriyet kısıtlayıcı yönü ile sürgün, kalebent ile hürriyet bağlayıcı yönü bulunan prangabent ve kürek cezalarının incelenerek Abdülmecid döneminde Osmanlı Devleti'nin ağır ceza uygulamalarındaki sorulara cevap aramaktır. Söz konusu cezalar, dönemin ağır ceza anlayışına ilişkin ipuçları içermesi bakımından ayrı bir değere sahiptir. Araştırma soruları olarak ağır cezalar ile suçluların hangi bölgelerden nerelere sürüldüğü, hangi durumlarda zorunlu ikamete tabi tutuldukları, ne sebeple ağır işlerde çalıştırıldıkları ve hangi suç ile bir kalede hapse mahkûm edildikleri meselelerinin aydınlatılması hedeflenmiştir. İşlenen suç çeşitliliğinin cezalandırma türünün belirlenmesinde temel etken olduğu görülmüştür. Araştırmada nitel araştırma yöntemlerinden doküman analizi yaklaşımı kullanılmıştır. Çalışmanın veri kaynaklarını Başbakanlık Osmanlı Arşivi'ndeki döneme ait belgeler oluşturmuştur. Ağır cezalar kategorisinde yer verilen sürgün cezasının incelediğimiz diğer cezalara nispetle daha fazla uygulandığı bulgusuna rastlanılmıştır.
\end{abstract}

Anahtar Kelimeler: Abdülmecid, kalebentlik, kürek, prangabentlik, sürgün.

\section{An Investigation on the Application of Liberty Binding and Restricting Penalty in the Abdülmecid Period}

\begin{abstract}
It is known that radical and serious steps were taken in the field of law with the Tanzimat period. The introduction of new legal regulations within the legal community and the beginning of their use are some of these steps. The aim of this research is to investigate the exile, fortress, shackles, penal servitudes punishments and to reveal the system in the heavy penal practices of the Ottoman Empire during the reign of Abdülmecid. The penalties in question have a separate value in that they contain clues to the heavy criminal understanding of the period. The questions of the research aim to clarify where the criminals with the heavy penalties were sent, in which cases they were subjected to compulsory residence, for what reasons heavy duty was employed or due to which crime they were
\end{abstract}

Gönderim Tarihi / Sending Date: 11/02/2020 Kabul Tarihi / Acceptance Date: 03/04/2020 
imprisoned in a castle. It has been observed that the variety of crime committed is the main factor in determining the type of punishment. Document analysis approach, one of the qualitative research methods, was used in the research. The data sources of the study are composed of documents belonging to the period found in the Ottoman Archives of the Prime Ministry. It has been found that the exile penalty in the heavy penalties category is applied more than the other punisments we have examined.

Keywords: Abdülmecid, exile, fortress, penal, servitudes and shackles. 


\section{GíRiş}

Ceza verme hak ve yetkisi, devlet başkanı ya da onun görevlendirdiği kişilere ait bir yetki olarak İslam hukukunda yer almıştır. Adaleti gözeterek hukuka uygun ceza vermek, insanları doğru yola sevk etmek, toplumdaki karmaşa ve ihtilafları halletmek devlet başkanının temel vazifelerindendir. İslam hukukunda suçlar, had gerektiren, kısas (diyet) gerektiren ve ta' zir gerektiren cezalar olarak sınıflandırılmıştır (Gökçen, 1987, s. 5-6).

Ta'zir' ${ }^{1}$ hem şer'i hem de örfi yönü bulunan, dolayısıyla din ile çelişmeyen fakat dini cezalandırma sistemini tamamlayan bir ceza grubu olarak karşımıza çıkmıştır. Osmanlı hukuku alanında yapılan çalışmaların detaylandırılması ve aydınlatılması noktasında geniş bir tatbik alanı bulunan ta'zir ceza grubunun önemli bir paydaya sahip olduğu aşikârdır. Bilindiği üzere geçmişte olduğu gibi günümüzde de adalet mekanizmasının güvenilirliği ve işlerliği devletin gücü ile doğru orantılı olarak değerlendirilmektedir. Şüphesiz hukuk sistemi üzerine pek çok araştırma yapılmaktadır. Söz konusu araştırma da bu noktada, Osmanlı hukuku alanında yapılacak olan çalışmalara katkı sağlayacaktır.

Abdülmecid döneminde her alanda olduğu gibi hukuk alanında da yeni adımların atıldığı bilinmektedir. Söz konusu dönem hukuk anlayışının aydınlatılması için hukuk tarihine kısa da olsa yer vermek yerinde olacaktır. Osmanlı Devleti'nin adalete bakışını anlayabilmek için devletin kurucusu olan Osman Bey'in ilk tayin ettiği memurlardan birinin kadı olması (İnalcık, 2008, s. 36), devletin adalete verdiği önemi ortaya koymaktadır. İlk Osmanlı kadıları Anadolu, İran, Suriye ve Mısır'dan getirilmiştir. Kadıların, Tanzimat dönemine değin çok geniş kapsamlı yetkileri olup, Tanzimat'tan sonra bu yetkileri azalmış ve Osmanlı' nın son dönemlerine doğru ise tamamen ellerinden alınmıştır (Uzunçarşıll, 1965, s. 87).

Tanzimat'ın ilanından itibaren Osmanlı hukuk sistemi yeni bir safhaya girmiştir. Batı medeniyetindeki gelişmeler doğrultusunda yeni hukuki düzenlemelere gidilmiştir. İlki 1838 yılında olmak üzere ceza kanunnamesi yayınlanmıştır. Bu kanunname biri kazasker, kadı ve naiplere diğeri ise memurlara yönelik olmak üzere iki ceza kanununu şeklinde tasarlanmıştır. Kadıların suiistimallerine set çekmek, rüşvetle mücadele etmek ve memurlarının vazifesini düzgün yapması için kaleme alınmış (Veldet, 1940, s. 170-171) fakat beklentileri tam anlamı ile karşılayamamıştır. 1840 yılında yeni bir ceza kanunnamesi daha yayınlanmıştır. Her iki kanunnamenin teknik ve içerik zihniyeti arasında büyük fark olduğunu ifade etmek mümkündür (Kaynar, 2010, s. 301). Avrupa fikriyatından esinlenerek oluşturulan bu kanunname 1 mukaddime, 13 fasıl (41 madde) ve hatimeden oluşmaktadır. Hükümdar ve devlet aleyhine işlenecek fesatlar, katl, fesat çıkarmak, dövmek, sövmek, mülke tecavüz, rüşvet, irtikap, vergi vermekten imtina, memurlara muhalefet, silah çekme, silah boşaltma, cerh, yol kesme suçlarına yer verilmiş ve cezaları kısas-ı şer'i, siyaseten katl, kürek, sürgün, tekdir, hapis ve memuriyetten çıkarma olarak tayin edilmiştir (Taner, 1941, s. 227). Önemli suçları ihtiva etmeyişi nedeniyle yine yetersiz kalmıştır. Bunu 1851 yılında

\footnotetext{
$\overline{1}$ Tekdir etme, sslah, terbiye etme anlamlarına gelen ta'zir mefhumunu, İslam hukukunda yer alan had ve kısas grubuna girmeyen suç ve günahlarda tayin ve miktarının belirlenme işinin devlet otoritesi yani ulül-emre bırakıldığı ceza grubu olarak tanımlamak mümkündür. Dolayısıyla İslam hukukunun asli kaynaklarında bu ceza grubunun hükümlerine yer verilmemiştir. Ta'zir ceza grubu iki temelde incelenebilir ki bunlardan birincisi; had veya kısas suçu iken, suç unsurlarından herhangi birinin eksik olması veya mağdur ya da yakınlarının suçluyu affetmesi durumunda had ile kısas cezalarının uygulanamaması durumunda suçun ta'zire dönüşmesi durumunda uygulanan cezalar, ikincisi ise had ve kısas grubuna girmeyen ve devlet otoritesi tarafından sınırları çizilerek uygulanan cezalardır. Osmanlı'da en çok uygulanan ta'zir cezaları ölüm, hapis, sürgün, sopa, müsadere, kınama, teşhir, kürek, prangabent, kalabent cezalarıdır (Yurtseven, 2001, s. 272).
}

SEFAD, 2020; (43): 497-518 
yayınlanan diğer bir ceza kanunnamesi takip etmiştir. Bu kanunname ilkine nispetle daha etraflıdır. Yazılış tarzı bakımından aynı olup bir mukaddime ve 3 fasıldan oluşmuştur. Fasılların her biri adeta birbirinden bağımsız kanunlar halinde tasarlanmıştır. 1840 kanunnamesine sarkıntılık, sarhoşluk, kumarbazlık, kız kaçırma, sahtekarlık, kalpazanlık gibi suçların eklenmesi şeklinde oluşturulmuştur. Diğer kanunnamelerden farklı olarak prangabent cezasına yer verilmiştir. 79 değneğe kadar olmak üzere dayak cezası kabul edilmiş ve bazı hallerde ise dayak cezası hapis cezasına tercih edilmiştir (Taner, 1941, s. 228). $\mathrm{Bu}$ kanunnamede temel hak ve hürriyetlerin güvence altına alındığını ifade etmek mümkündür (Çadırcı, 1997, s. 203-207). Önemli yenilik ve ilerilik arz etse dahi yine de yetersiz kalmıştır. Bunun üzerine 1858 yılında yeni bir ceza kanunnamesi daha ilan edilmiştir. 1 mukaddime ve 3 baptan oluşan bu kanunname, diğerlerine nispetle çok daha kapsamlı ve etraflı olup 68 yıl boyunca uygulamada kalmıştır (Taner, 1941, s. 230). Birinci bap ammeye yönelik suçlar, ikincisi şahıslar aleyhine işlenen suçlar ve üçüncüsü ise kabahatler olarak tayin edilmiştir. Cinayet, cünha ve kabahat olarak tasnif edilmiştir. Cinayet suçları idam, müebbet veya muvakkat kürek, müebbet veya muvakkat kalebentlik, nefy, müebbeden rütbe ve memuriyetten mahrumiyet; hukuki medeniyetten 1skat anlamina gelen cünha suçları 1 haftadan 3 seneye kadar hapis, muvakkat nefy, memuriyetten tard ve para cezaları; kabahat suçları ise 24 saatten 1 haftaya kadar hapis ile 100 kuruşa kadar para cezasını ihtiva etmiştir (Taner, 1941, s. 231).

Araştırma, hürriyet kısıtlayıcı cezalar olarak karşımıza çıkan sürgün ve kalebent ile hürriyet bağlayıcı yönü bulunan prangabent ve kürek cezaları ekseninde devletin dönemsel olarak ağır ceza uygulamalarındaki sistemi ortaya çıkarmayı hedeflemiştir. Suçluların nasıl ıslah edildiği, ailelerin bu cezalardan nasıl etkilendiği, cezaların süreleri ve cezalara ne şekilde son verildiği gibi konular hakkında bilgi sunulacaktır. Osmanlı'da sürgün, genel çerçevede iki şekilde uygulanmıştır. Bunlardan ilki iskân siyasetinin gereği olarak uygulanan ve cezalandırılma mahiyeti taşımayan toplu sürgün uygulaması, diğeri ise suç işleyen bireylerin bulundukları bölgeden uzaklaştırılıp, başka bir bölgede belli bir süre için yaşamaya mahkûm edilmesi durumudur (Daşcioğlu, 2010, s. 167-168). Devlet kuruluş ve yükseliş döneminden itibaren yeni fethedilen topraklara, merkezi otoriteyi kuvvetlendirmek amacı ile konar-göçer Türk unsurunu sevk etmiş ve yerleştirme politikası olarak sürgün yöntemine sıklıkla başvurmuştur. Aşiretlerin cezalandırılması amacıyla da yapılan bu yer değiştirme hareketi ile yerleşik ahalinin korunması hususuna önem verilmiştir (Halaçoğlu, 2014, s. 137).

Osmanlı Devleti ağır cezalar kategorisinde yer alan sürgün, kalebent, prangabent ve kürek cezaları ile suçluların ıslah edilip topluma kazandırılması ve yapılan olumsuz davranışlar neticesinde verilen ağır cezaların yaptırımı ile aynı fiilin başkaları tarafından da ifa edilmesini önlemeyi amaç edinmiştir. Uygulanan cezalar ile devletin kurumsal yapısına zarar veren ya da toplumda huzursuzluğa sebep olan şahısların öncelikle bu davranışlarından arınmaları ve bir daha suç eylemine karışmamaları sağlanmaya çalışılmıştır. İdam cezaları dışında uygulanan cezaların bütününde bu amaç gözetilmiştir. Yerel yöneticilerin, suçluların benzeri davranışları bir daha yapmayacağına kanaat getirmeleri halinde, merkezden serbest birakılmalarına dair irade talep edebilmeleri bunun göstergesidir.

Ağır ceza kategorisinde yer verilen ceza çeşitlerinde 1 slah-1 nefs ibaresinde yer verilmiştir. Dolayısıyla ceza süreleri muğlak bırakılmış, cezalar belirli bir süre için ya da süresiz olarak uygulanmıştır. Suçlu bulunan şahıs muvakkat olarak gönderilmiş ise islah-1 
nefs edinceye dek, müebbet olarak gönderilmiş ise ömür boyu kendisine uygun görülen cezayı çekmeye mahkûm edilmiştir. Cezalandırılma uygulamasında şahısların nefsini ıslah etmesi beklendiğinden tek tip ve belirli süreli bir ceza uygulamasından söz etmek mümkün değildir. Tanzimat'ın üzerinde durduğu prensiplerden biri de cezaların bireyselliği yani suçu kim işlemiş ise cezanın yalnız ona çektirilmesi meselesidir (Taner, 1940, s. 224). Ailelerin bu cezalardan asgari seviyede etkilenmesine dikkat edilmiştir. Ceza alan şahısların ailelerine bakacak kimsesi olmadığ indirim yapılması aile bütünlügüune verilen önemi gösteren özellikler olarak karşımıza çıkmıştır.

Abdülmecid döneminde ilan edilen Tanzimat'ın getirdiği yeniliklerle değişen hukuk anlayışı çerçevesinde kanunnamelerde yer verilen ağır cezalara (sürgün, kalebent, prangabent ve kürek) devletin yaklaşımı ve ceza sistemi içerisindeki yerlerinin incelenmesi amaçlanmıştır. Ağır ceza uygulamalarının aydınlatılması yönünde çok fazla çalışma yapılmamıştır. K. Daşcıoğlu, A. Acehan, M. Ç. Uluçay, E. Taşbaş sürgün cezaları, G. Alan kadın sürgünler, N. Erim kalebentlik cezaları ile ilgili eserler verirken, biz hürriyet bağlayıcı cezalar olan sürgün, kalebent ile hürriyet bağlayıcı olan prangabent ile kürek cezalarını inceleyerek Abdülmecid dönemi ağır ceza anlayışındaki boşluğu dolduracağız.

\section{Abdülmecid Dönemi Ağır Cezalar}

İslam hukukunda ta'zir ceza grubu içerisinde yer alan ağır cezaların suç ya da cezasına dair bilgilere yer verilmemiştir. Bu suç grubuna verilecek cezayı ulül-emr tayin etmiş (Üçok; Mumcu; Bozkurt, 2016, s. 101-102); dolayısıyla takdir hakkı padişaha bırakılmıştır. Teşhir, dayak atma, para cezası, kürek cezası, kalebentlik, sürgün gibi cezalar bu türden cezalar içerisinde yer almıştır. İhtardan idama kadar geniş bir tatbik alanı mevcuttur (Akgündüz, 1990, s. 8).

Hz. Ömer zamanından itibaren hukuksal anlaşmazlıkları çözmek amacıyla şeriatı iyi bilen ve mahkûmiyeti bulunmayan Müslümanlar arasından kadılar tayin edilmiştir (Üçok; Mumcu; Bozkurt, 2016, s. 102-103). Osmanlı Devleti'nde de kadılar, kadılık bölgesinde meydana gelen basit, gündelik ve sıradan suçlar olarak nitelendirebileceğimiz suçların tespitini yapmış, cezasını ise yerel yöneticiler uygulamıştır. Önemli görülen hallerde kadılık tarafından durum merkeze gönderilip, divana havale edilmiş, buradan konu ile alakalı ferman ya da buyuruldu düzenlenmiş ve tekrar kadılara sevk edilerek ceza uygulamasına geçilmiştir (Erim, 1984, s. 80).

16. yüzyılda Osmanlı donanmasının büyümesine bağlı olarak artan kürekçi ihtiyacının karşılanması için kürek cezasına sıklıkla başvurulmuşken (Erim, 1984, s. 81), 18. yüzyılda bu ihtiyacın azalması sonucu diğer cezalara ağırlık verilmesi gibi Osmanlı Devleti'nde cezalandırma şekilleri zamanın ihtiyaçları doğrultusunda değişkenlik arz edebilmiştir.

\section{A. Cezalandırılma Çeşitleri}

Araştırmanın ilk temel ayağını cezalandırılma çeşitleri meselesi oluşturmuştur. Bu kategoride incelemeye konu olan ağır cezalar derecelerine göre sınıflandırılmış ve dört alt kategoriye ayrılmıştır. Bunlar sürgün, kalebent, prangabent ve kürek cezalarıdır.

\section{Sürgün Cezası}

Tanzimat'tan sonra ilan edilen 1840 Ceza Kanunnamesi'nin 4/2 maddesinde devletin yasakladığı maddelere cesaret eden olur ise birinin mal ve mülküne tasallut veya hilaf-ı rıza 
harekete cesaret etmesine binaen memuriyetten tard ve ihraç ile memleketten başka mahalle nefy ve tağrib şeklinde yer verilmiştir (Kaynar, 2010, 306). Daha sonra yayınlanan ceza kanunnamelerinde de sürgün hükümleri yer almıştır (Akgündüz, 1990, s. 10). Abdülmecid dönemine ait incelediğimiz belgelerden yola çıkarak sürgünün ağır cezalar içerisinde en fazla başvurulan cezalandırma şekli olduğu çıkarımına gidilmiştir. Bu ceza ile suçlular bulunduğu bölgeden uzaklaştırılmış ve belirlenen süre içerisinde gönderildiği bölgede, nefsini ıslah edinceye dek, yaşamıştır. Suçlular gönderildiği bölge sınırları içerisinde serbestçe yaşayabilme imkânına sahip olmuştur. Muvakkat cezalar 3 aydan 5 yıla kadar verilebilmiştir (Kaynar, 1940, s. 307-311). Kalebent olan birisinin cezası sürgüne çevrildiği takdirde ise ceza süresi on beş yllı bulabilmiştir (Gökçen, 1987, s. 69).

Dönemde sürgün cezasına sebep olan haller olarak; Tanzimat'a yönelik isyan girişimleri, kendi halinde olmamak, fitne ve fesat olmak, düzeni bozmak, eşkıyalık, halkı kışkırtmak, firar, rüşvet, iftira atmak, ahaliden zorla para almak, alacağından fazla para talep etmek, katl, haneye tecavüz, ırza tecavüz, hakaret ve küfür, yardım ve yataklık, cemaat ile iyi geçinmemek, hırsızlık, resmi evrakta sahtecilik gibi suçlar karşımıza çıkmıştır. Devlet memurlarının da bu cezalara çarptırıldığı görülmüştür. Kimi memurlar maaşı kesilmeden, ailesi ile birlikte sürgüne gönderilmiş ve gittikleri yerlerde müreffeh fakat küskün bir hayat yaşamıştır. Kimi memurlar çok kısıtlı eşya ile sürgüne gönderilmiş ve sadece kendisine tahsis edilen aylıkla geçinmeye mahkûm edilmiştir. Diğer bir kısmı ise sadece giyecek elbisesi verilerek, sürgün bölgesinde zor ve sıkıntılı bir hayat sürdürmüş ve zorunlu ikamete tabi tutulmuştur (Uluçay, 1951, s. 508). Devlet memurları sürgüne gönderilmeden önce rütbeleri de feshedilmiştir. Bununla alakalı olarak 1839 yılında Tırnova Odunpazarı kazası müdürü Salih'in (A.DVN, 51/7) rütbesi feshedilerek sürgüne gönderilmesi, 1844 yılında Harem-i Hümayun Türbedarlığı görevinde bulunup, Rikab-1 Hümayun kapıcıbaşllğı görevine getirilen Hüseyin Ağa'nın uygunsuz hareketleri nedeniyle (İ.DH, 82/4134) rütbesinin feshedilip Edirne'ye sürgüne gönderilmesi ve 1853 yllında Meclis-i Vâlâ üyelerinden olan Osman Paşa'nın (İ.DH, 457/30321) rütbesinin feshedilip sürgüne gönderilmesi meseleleri ile karşılaşılmıştır.

Usule aykırı hareket etmek devlet memurlarının sürgün sebeplerindendir. 1853 yılında Sındırgı, Bigadiç ve Kepsut kazaları müdürleri ile meclis azalarının, asakir-i redife maddesine uymayarak, ertelemeleri olduğu halde 142 nefer askeri, usule aykırı olarak göndermeleri üzerine görevlerinden ihraç edilmişlerdir. Ardından Sındırgı ve Bigadiç kazaları naiplerinin 6 ay müddetle Balıkesir'e, Kepsut naibinin ise 4 ay müddetle Mihaliç'e sürgüne gönderildiği (İ.MVL, 290/11568) tespit edilmiştir. Bu gibi hallerde sürgüne gönderilmeden önce suçluların borçlarını ödemesi beklenmiştir. Bu nedenle devlet vekil tayini yapabilmiştir. 1853 yılında Bursa'ya sürgüne gönderilmiş olan Behkeli Mehmet Paşa, Saraylı Fazıl Paşa ile Madenli Derviş Bey'in borçlarının tespit edilip ödenmesi amacıyla Hüdavendigar valisinin vekil olarak tayin edilmesi (İ.MVL, 288/11443) bununla alakalı olarak karşımıza çıkan meselelerden olmuştur.

Medrese talebeleri ya da şeyhlere de sürgün cezaları uygulanmıştır. Nasiri Şeyhî Abbas'ın 1848 yılında terbiye edilmesi için Sinop'a sürgüne gönderilmesi (İ.MVL, 76/2175), 1858 yılında ise Manastır sakinlerinden ve ulema talebesi olan Abdullah Efendi'nin hocası İbrahim Efendi'nin dersinden uzaklaştırılarak Pirlepe kazasına sürgüne gönderilmesi (İ.MVL, 396/17231) karşımıza çıkan meselelerdendir.

Suçun bireyselliği ilkesine önem verilmiştir. Üst düzey yöneticilerin aile bireyleri suç unsuruna karıştığı takdirde sadece suç işleyen şahıslar cezalandırılmıştır. 1858 yılında Sayda 
Defterdarı Mustafa Efendi'nin oğlu Ali Bey'in, gardiyan Andon'u değnekle döverek öldürmesi üzerine Kıbrıs'a sürgüne gönderilmesi meselesi ile karşılaşılmış ve devlet memuru olan babasının ise görevini ifa etmeye devam ettiği tespit edilmiştir (A.MKT.MHM, 150/4). Ailelerinin mağduriyet yaşamamasına da önem verilmiştir. Bu nedenle kimi zaman suçluların aileleri ile sürgüne gönderilmelerine de izin verilmiştir. Aile fertleri ile beraber sürgüne gönderilmiş olan suçlular, uzun süre sürgünlük yaşadıktan sonra gönderildiği bölgede tutunup, cezasını tamamladığı halde memleketine dönmek yerine sürgün bölgesinde yaşamaya devam etmiştir. 1861 yılında Musul'dan sürgüne gönderilen kalabalık bir ailenin yaklaşık 5-6 senedir sürgün bölgesinde olup bölgede yaşamaya devam etme isteklerini bildirmesi bunun örneklerindendir. Bölgede tutunmuş olduklarını öne sürerek Musul'da kalan mülklerinin başkasının eline geçmeden satılması için talepte bulunmuşlardır. $\mathrm{Bu}$ amaçla bir mübaşir tayin edilmiş ve küçük kardeşleri ile birlikte onun bölgeye gönderilmesine onay verilmiştir (MVL, 928/31).

Menfiler $^{2}$ sürgüne gönderildikten sonra geride bıraktıkları mal ve mülklerinin tahsilini de talep edebilmiştir. Bu durumlarda, malların tespit ve tayini için mübaşir ataması yapılmıştır. 1853 yılında Konya sancağı Sarıkeçili ve Denizli aşiretlerinden Silifke kazasına sürgüne gönderilmiş olan Ali Ağa'nın, kalan mallarının tayin ve tespiti için mübaşir tayin (İ.MVL, 288/11463) edilmesi bunu doğrular niteliktedir. 1850 Ceza Kanunnamesinde sürgünde mal ve mülkü bulunan erkek ya da kadın suçluların, vefat etme ve herhangi bir yakını bulunmaması durumunda terekesinin beytülmale ait olması hükmüne yer verilmiştir (A.MKT.MVL 19/80). Sürgün mülkünü bağışlayacak olan şahsın herhangi bir engeli yok ise mahallesi imamı, muhtarları ve birkaç nefer ahali ile mahalle mahkemelerinden birine gidip ya da gitme gücü olmayıp engeli bulunduğu takdirde ise mahkemeden bir kâtip gönderilip imam, muhtar ve yerel ahaliden birkaç kişiden oluşan heyete; aklı başında, şuuru yerinde ve gönül rızasıyla vasiyetini verdiğini beyan ederek (A.MKT.MVL 19/80) bağışta bulunacaktır. Durumun Meclis-i Vâlâ ve Maliye Hazine-i Celilesi'ne bildirilmesi karara bağlanmıştır.

Menfalarında maddi güçlük çeken menfiler ile alakalı günlük yevmiye miktarı üzerinden maaş tahsisi uygulamasına gidilmiştir. 1860 yılında Cidde kaymakamı İbrahim, Yusuf Patacı, Ömer Barok ve 19 nefer askerin Kıbrıs'a sürgüne gönderilmeleri üzerine askerlere yevmiye tahsisine onay verilmesi meselesinde (A.MKT.MHM, 175/4), askerlerin ziyadesiyle maddi güçlük çektikleri belirtilerek her birine günlük birer çift ekmek bedeli olan birer kuruşun (A.MKT.MHM, 164/56) tahsisine izin verildiği anlaşılmaktadır. Sürgüne gönderilen menfilerin geride bıraktıkları aileleri maddi güçlük yüzünden mağdur olduğunda da aynı uygulama geçerli olmuştur. 1851 yılında Cizre sancağından Bedirhan Bey ile Şeyh Azrail'in Girit'e sürgüne gönderilmeleri üzerine mağdur olan ailelerine 150 kuruşluk maaş tahsis edilmesi (A.AMD, 28/18) karşımıza çıkan meselelerdendir. Cizre Hâkimi olan Bedirhan Bey'in Osmanlı Devleti'nin Nizip Savaşı (1839) sonrası merkezi otorite boşluğu ve halkın da devlete karşı tutumundan yararlanarak bölgeyi hakimiyeti altına almak için isyan ettiği bilinmektedir (Öğün, 2010, s.33-43)3.

\footnotetext{
${ }^{2}$ Nefy olunmuş, memleketten sürülmüş, icla olunmuş ve sürgün edilmiş kimse anlamına gelmektedir (Sami, 1996, 1419).

${ }^{3}$ Aşiretçilik geleneğinin etkin olduğu Cizre bölgesinde Bedirhan Bey, devlete karşı asi tavrını gün geçtikçe artırmış ve başına buyruk hareket etmeye başlamıştır. Osmanlı Devleti tarafından Bedirhan Bey asi ilan edilmiştir. Aynı aileye mensup yeğeni İzzeddin Şîr Bey'in Osmanlı safında yer alması isyanın bastırılması noktasında devlete ciddi anlamda katkı sağlamıştır. Ardından Diyarbakır, Van, Muş, Hakkâri, Cizre, Bohtan ve Mardin sancaklarından oluşan yeni bir eyalet oluşturulmuştur. Sultan Abdülmecid'in söz konusu bölgenin gerçek fatihi olduğunu vurgulamak üzere bu eyalete 1847 yılında Kürdistan adı verilmiştir.
} 
Menfilerin sürgüne gönderildikten sonra, özel durumlarda memleketlerine dönebilmelerine izin verildiği de tespit edilmiştir. Bu gibi hallerde yol harçlıkları da devlet tarafından karşılanmıştır. 1848 yılında Maçin'e sürgüne gönderilen Boyarlar'dan iki kişinin memleketlerine gönderilmesi için ruhsat verilip, her ikisi için de 1500 kuruş yol harçlı̆̆ tahsis edilmesi bunu kanıtlamaktadır. Memleketlerine iade sebepleri; birinin çok genç yaşta olup hava değişikliğine ihtiyacı olduğunun düşünülmesi, diğerinin ise Yaş'taki çiftlikleri tamamen zapt edilip, konağına hastane yapıldığından ailesinin muhtaç duruma düşmesi olarak belirtilmiştir. Muhtaç durumda kalan aileye aylık 200 kuruş maaş tahsis edildiği de anlaşılmaktadır (İ.MSM, 66/1896). Bu noktadan hareketle ailenin sürgün nedeniyle yaşadığı mağduriyetin giderilmeye çalışıldığı sonucuna ulaşılmıştır. Menfilerin çeşitli gerekçelerle sürgün yerlerinde değişiklik yapılabildiği de tespit edilmiştir. 1860 yılında İstanköy kalesine sürgüne gönderilmesine karar verilen Gaffar'ın Türkçe bilmediği gerekçesi ile menfasının ${ }^{4}$ Kıbrıs olarak değiştirilmesi (İ.DH, 450/29733), 1861 yılında Rodos'a sürgüne gönderilmiş olan Farukizade Abdülhadi Efendi'nin göğüs hastalığına yakalanmış olması nedeniyle sürgün yerinin Mekke-i Mükerreme olarak değiştirilmesi (İ.DH, 479/32190) bunu kanıtlar nitelikteki verilerdendir. Dolayısıyla zorunlu görülen haller olarak ifade edebileceğimiz gönderildiği bölgenin dilini bilmeme ve sağlık problemleri gibi nedenler yer değiştirmenin temel sebebi olmuştur. İşlenen suçun büyüklügüne göre bazı durumlarda menfilerin, memleketine ayak basmama şartı ile sürgüne gönderildiği de tespit edilmiştir. 1840 yılında Trablus'ta ahali reisi olan Mehmet, Kürt Mehmet ve mülki müfettiş Abdülislam'ın memleketlerine ayak basmamak üzere Der-saadet'e sürgüne gönderilmeleri (HAT, 453/22439) bununla alakalıdır. Yine bir başka meselede ise 1854 yılında Selanik serserilerden olup, bölge halkına her türlü fenalığı yapan Rahofçalı Ferhat, Abdullah, Sait ve Prizren Topalak karyeli Selim'in memleketlerine ayak basmamak üzere Kıbrıs'a sürgüne gönderilmeleri (İ.MVL, 302/12370) ile karşılaşılmıştır.

Menfilerin menfalarına sevk edilebilmesi işinin, belli bir bütçe tahsisini gerektirdiği aşikardır. Bütün bu nakil işlemleri için gerekli olan masrafların Maliye Nezareti'nden Zaptiye Nezareti'ne havale edilerek gerçekleştirildiği tespit edilmiştir. Temmuz ile Eylül 1852 (1268) dönemi arasındaki toplam masraf olan 9.650 kuruşun 6.472 kuruşu gemi masrafı, 3.064 kuruşu sürgün ve 114 kuruşun ise hesapta olmayan çeşitli masraflar için tayin edilip Maliye Nezareti'nden talep edildiği anlaşılmaktadır (İ.DH, 264/16477). Yine 1854 yılında çeşitli yerlere sürgüne gönderilen menfilerin gemi vb. sevkiyat masrafları nedeniyle ortaya çıan 430,5 kuruşun aynı şekilde havalesinin de (İ.MVL, 303/12409) gerçekleştirildiği tespit edilmiştir. Menfilerin menfalarına sevki mübaşir tayini ile yapılmıştır. Menfinin memuriyetteki konumuna binaen yeterli sayıda kavvas ${ }^{5}$ adı verilen silahlı çavuş da bu amaçla görevlendirilmiştir. Mübaşir ile çavuşların masrafları yine devlet tarafından karşılanmıştır. 1847 yılında Ayvalık'ta meydana gelen kargaşada parmağı olan birkaç kocabaşın sürgüne gönderilmesi meselesinde, suçlulara eşlik etmek üzere Selami Efendi (mübaşir) ile 5 kavvas (silahlı çavuş) görevlendirilmiş ve onların 5 günlük masrafları için 7.500 kuruş harcırah belirlenmiş ve havalesi yine aynı şekilde gerçekleştirilmiştir (İ.MSM, 83/2361).

Elde edilen verilerden ulaşılan bulgulara göre dönemde başvurulan ağır cezalardan olan sürgün cezasının diğerlerine nispetle daha fazla olduğu ve bu cezaya ağırlıklı olarak başvurulduğu çıkarımına gidilmiştir.

${ }^{4}$ Nefy sürgün yeri, menfi sürgün edilen, menfa sürgün yeri anlamlarına gelmektedir (Sami, 1996, s. 1418-1419).

${ }^{5}$ Büyük amirler hizmetinde çavuş, emir çavuşu (Sami, 1996, 1086). 


\section{a. Sürgün Yerleri}

Araştırma sorularından biri de ağır cezalar ile suçluların hangi bölgelerden nerelere sürüldüğü meselesinin aydınlatılması olarak belirlenmiştir. Bu noktadan hareketle sürgün yerlerinin belirlenmesinde suçun mahiyeti, niteliği, suçlunun makam ve mevkii veya statüsünün göz önüne alınıp alınmadığı gibi temel sorunlar irdelenmiştir. Karşılaştığımız meselelerde devlet görevlilerinin ulaşım imkânları zor ve kısıtlı olan adalara sürgüne gönderildiği anlaşılmıştır. Bununla alakalı olarak, 1853 yılında Erzurum Tercan kazasından Selanik'e müderris Halet Bey'in işleri ile ilgilenmek üzere gönderilen Kör Ali adlı şahsın, daha sonra Yusuf Paşa'nın valiliği döneminde bölükbaşılığı görevine getirilmesi ve bu görevde iken Siroz bölgesinde irz ve namus gibi uygunsuzluklara cesaret etmek bir yana, Selanik bölge halkını 15-20 bin kuruş dolandırıp, 4-5 senedir halkı bezdirdiği meselesi ile karşılaşılmıştır. Suçunun tespit edilmesi üzerine Kör Ali adlı şahıs, Kıbrıs adasına müebbet olarak sürgüne gönderilmiştir (İ.MVL, 293/11785). Ağır suçlarda menfilerin kaçma riskini azaltabilmek için çoğunlukla sahil kaleleri veya adalar tercih edilmiştir. Adaların kısıtlı imkânlara sahip olması da tercih edilme nedenlerindendir. 1853 yılında Cebel-i Garbiye'de itaatsizliğe cüret etmiş olan Nalut, Kabav ve Havamid kazaları ahalisinden 50 kadar kişinin yakalanarak Trablus'ta hapsedilmesi ve prangabent olarak ceza çekmeleri ardından Mihaliç'e kalebent olarak gönderilip, 4-5 ay sonra ise Girit'e gönderilmeleri (İ.MVL, 303/12447) bunu kanitlamaktadır.

Sistemli bir sürgün politikasının takip edilip edilmediği, güzergahların tesadüfen mi yoksa sistemli olarak $\mathrm{m}$ s seçildiği sorularına da yanıtlar aranmaya çalışılmıştır. Hafif suçlarda yakın yerlerin, gelişmiş şehirlerin ya da eyalet içinde farklı bölgelerin seçildiği bulgusuna ulaşılmıştır. 1847 yılında Nevşehir sancağı Ürgüp kazası ileri gelenlerinden ve Rum taifesinden olan Haci Sitte adlı zimminin, asayişi ihlal eden tavırlar sergilemesi üzerine, 5 ay müddetle Kayseri'ye (A.DVN, 26/90) sürgüne gönderilmesi meselesinde asayiş ihlali meselesindeki sürenin kısalığı ve bölgenin yakınlığı bunu kanıtlamaktadır. 1854 yılında Divriği kazası müdürü olan Abdi Efendi'nin düzeni koruyamaması nedeni ile azledilerek, Abdülkadir Ağa, Molla Mehmet, Mehmet Ağa ve Hüseyin Bey zade Emin Ağalar ile eyalet içinde uygun kazalara gönderilmeleri meselesinde (İ.MVL, 309/12843) de yine yakın bir sürgün bölgesinin seçildiği anlaşılmaktadır. Dolayısıyla suç dereceleri hafif ise ceza sürelerinin kısa, ceza yerlerinin ise yakın bölgelerden seçilmiş; suç derecesi ağırlaştı̆̆ında ise ceza sürelerinin uzayıp, ceza bölgeleri de uzaklaşmıştır. 1853 yılında Selanik Pazargah nahiyesindeki Kargı Gül mahallesinde hırsızlık suçu işleyen Arif, Sofiler mahallesinden Ali, Kuzelli mahallesinden Salih adlı şahısların ahaliye zarar verip, İnkel velet Dimo adlı zimminin 500 kuruşunu da gasp edip, firar etmeleri, Ali ile Arif'in yakalanması, Salih'in ise ele geçirilememesi Salih'in kardeşi Abdullah Pehlivan'ın kardeşini getirmek şartıyla süreli şekilde tahliye olunması, fakat bu kez de Abdullah Pehlivan'ın geri dönmeyip 2 ay kadar gezdikten sonra Kürt Ali, Ahmet, Salih ile birleşip, Papaz Dimo'yu katledip yine firar ettikleri (İ.MVL, 302/12336) tespit edilmiştir. Bu kez de Selanik'te 1854 yılında Salih, Mahmut, Kürt Ali, Topal Ali, Zeynel, Hacı Ali, Tabaka oğlu Ali, Turşuluk oğlu Ali ve Abdi adlı şahıslar yine fakirlere musallat olmuş, akçesini gasp ettikleri Engel'ı, hanesine girdikleri Simyob'u ve babasını katletmişlerdir. Suç çetesi haline gelen suçluların ele geçirildikten sonra Selanik'ten Magosa'ya yani uzak bir bölgeye, kalebent olarak gönderildikleri (İ.MVL, 302/12336) bulgusuna ulaşılmıştır. Kıbrıs'ın şartları açısından en ağır kalebentlik bölgesinin Magosa kalesi olduğu bilinmekte (Taşbaş, 2012, 194) olup bu nedenle

SEFAD, 2020; (43): 497-518 
bölgenin tercih edildiği anlaşılmaktadır. Dolayısıyla sürgün politikasında sistemsel bir düzen anlayışından bahsetmek mümkün görünmektedir.

Memleketi dişında yaşayan suçluların, sürgün cezaları alma durumunda kendi memleketlerine de gönderilebildiği bulgularına rastlanmıştır. 1844 yılında Mosis velet Agop adlı zimminin Der-Saadet'e gelmemek üzere memleketi Ankara'ya sürgüne gönderilmesi (A.DVN, 3/77) bunu doğrulamaktadır. Sürgündeyken ikinci bir suç işlendiği takdirde suçluların başka bir sürgün bölgesine gönderildiği verilerine ulaşılmıştır. Konya'da sürgünde bulunan Kör Haci İlya, Yağcı oğlu Yuvaki adlı zimmilerin, fakirlerin mallarını yağmalayıp, eziyetle almaya devam etmekte olduğundan 1847 yılında ikinci bir sürgün bölgesine daha gönderilmesi (A.DVN, 32/8) bunu kantlamaktadır. Bu bölge, birinciye nispetle daha uzak ve şartları daha ağır bir bölge olarak seçilmiştir. Elbistan kazası köylerinden Yapalak Kebir sakinlerinden Molla Hasan'ın ilk sürgün bölgesinin Sivas'ın Darende kazası iken, ikinci sürgün bölgesinin 1847 yılında Güzelhisar-1 Aydın olarak belirlenmesi (A.MKT, 103/80) bunu doğrulamaktadır. Bazen bu gibi ikinci suç işleme hallerinde memleketine bir daha ayak basmama şartı da getirilebilmiştir. Firar girişimlerini engelleyebilmek için ailelerin de menfalara gönderilebildiği verilerine ulaşılmıştır. Bununla alakalı olarak sürgün süresini tamamlayıp, ıslah-1 nefs etmemiş olan Hüseyin Bey'in firar etme ihtimalini ortadan kaldırabilmek için önlem amacıyla 1848 yılında eş ve çocukları ile beraber Girit'e sürgüne gönderilmesine onay verilmesi (İ.DH, 172/9205) meselesi karşımıza çıkmıştır.

Menfiler sürgün bölgelerine karayolu ile gidecek ise değişik yollar takip edilmiş ve coğrafi açıdan ulaşımı en uygun olan nakil aracı seçilmiştir. Deniz aşırı sürgünler için ise limanlar ve sahil kentleri kullanılmıştır. Ege ve Marmara adalarına yapılacak sürgünlerde, çoğunlukla İstanbul ve Gelibolu limanları kullanılırken, Anadolu'dan yapılacak sürgünler için ise Mersin limanı tercih edilmiştir (Acehan, 2008, s. 18). Karşılaştığımız belgeler ekseninde dönemde 68 adet sürgün yeri saptanmıştır. Verilere dair bilgiler Tablo 1 ve Şekil 1 'de sunulmuştur.

Tablo 1: Abdülmecid döneminde sürgün bölgeleri

\begin{tabular}{||l|l|l|l|l||}
\hline Adana & Bozok & Güzelhisar-1 Aydın & Kütahya & Sinop \\
\hline Akşehir & Bursa & Hadim & Magosa & Siroz \\
\hline Amasra & Çıldır & Hanya & Mardin & Sis \\
\hline Amasya & Çankırı & Hicaz & Merzifon & Sivas \\
\hline Amediye & Çarşamba & İstanköy & Midilli & Tilos \\
\hline Ankara & Darende & İzmir & Mihaliç & Tokat \\
\hline Aynaroz & Denizli & Karahisar-1 Gölhisar & Niş & Trablusgarp \\
\hline Bağdat & Dimetoka & Karahisar-1 Sahip & Pirlepe & Trabzon \\
\hline Balıkesir & Diyarbakır & Kavala & Rodos & Tur-i Sina \\
\hline Banaluka & Drama & Kayseri & Sakız & Van \\
\hline Beyrut & Edirne & Keftire & Samsun & Varna \\
\hline Bilan & Erzurum & Kibrıs & Sayda & Vidin \\
\hline Bolu & Girit & Konya & Selanik & \\
\hline Boyabad & Güzelhisar & Küçük Çekmece & Silifke & \\
\hline \hline
\end{tabular}

Tablo 1'de görüldüğü üzere sürgünler yoğunluklu olarak Anadolu coğrafyasına yapılmıştır. Mükerrer sürgün bölgelerinin varlığı sistemli bir sürgün politikasının takip edildiğini ortaya koymaktadır. Tespit edilen mükerrer sürgün bölgeleri; Adana (3), Ankara 
(4), Bolu (3), Bursa (3), Denizli (2), Diyarbakır (2), Edirne (2), Girit (4), İstanköy (2), Kayseri (2), Kıbrıs (8), Konya (2), Kütahya (4), Rodos (6), Selanik (4), Sinop (2), Trabzon (3), Varna (2) ve Vidin (4) şeklinde karşımıza çıkmıştır. Adalara gönderilen sürgünlerin diğer bölgelerden daha fazla olduğu bulgusuna ulaşılmıştır. Adalar içerisinde sekiz sürgün ile Kıbrıs, en fazla tercih edilen bölge olmuştur. Verilerden hareketle sürgün haritası da oluşturulmuştur (Şekil 1).

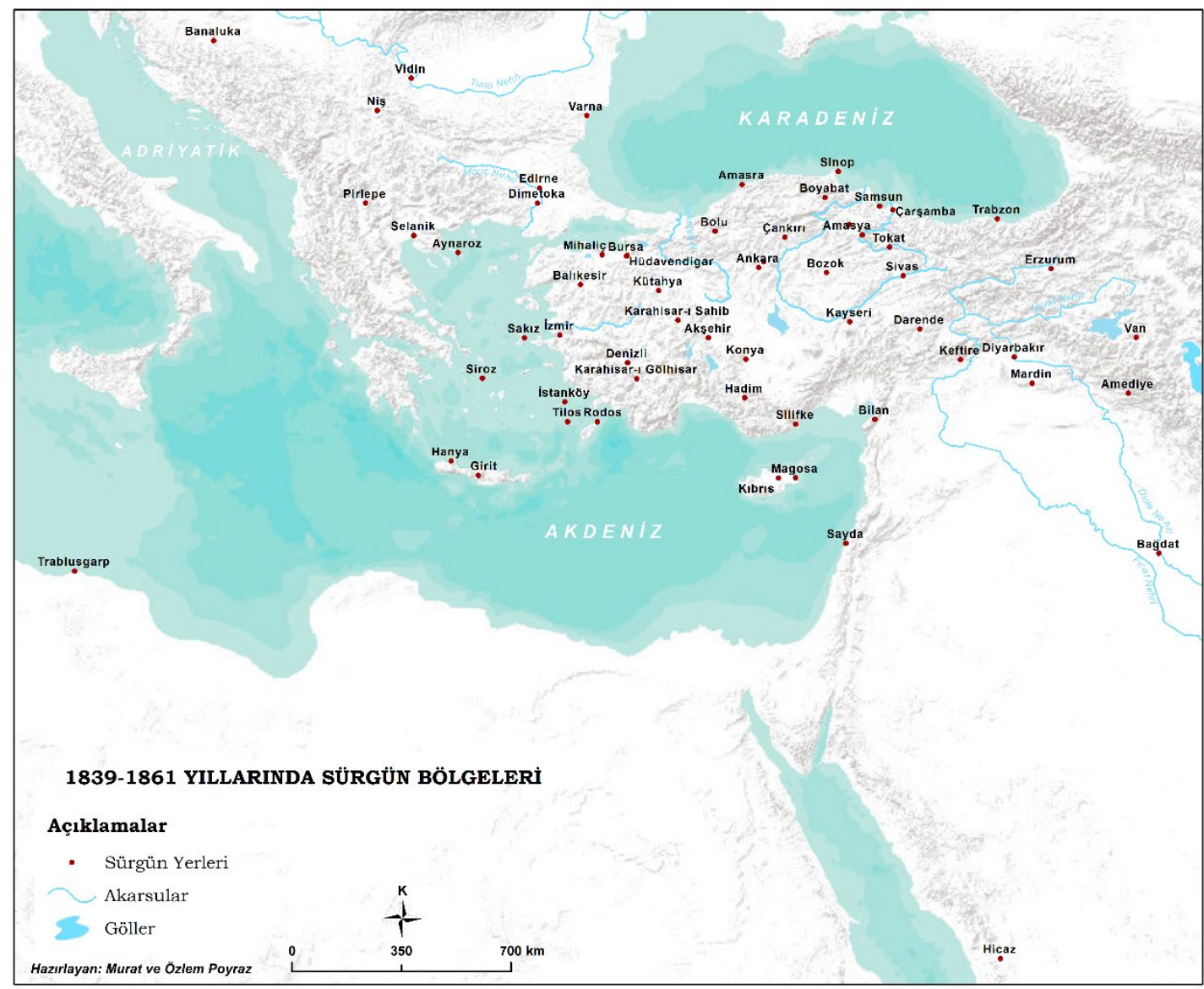

Şekil 1: Abdülmecid döneminde seçilen sürgün yerleri haritası

Şekil 1'den hareketle sürgünlerin geniş bir bölgeye dağıldığı çıkarımına gidilmiştir. Balkanlar'daki en uzak sürgün bölgesinin Banaluka (Banja Luka), Kuzey Afrika'daki en uzak sürgün bölgesinin Trablusgarp, Orta Doğu'daki en uzak sürgün bölgelerinin Sayda ve Bağdat, Arabistan'daki en uzak sürgün bölgesinin ise Hicaz olduğu tespit edilmiştir.

Ceza verirken devletin dikkat ettiği temel nokta, bireyin bireye karşı olumsuz davranışları ile bireyin topluma ya da devlete karşı yapmış olduğu davranışları, ceza bazında birbirinden farklı olarak ele almasıdır (Poyraz, 2017, s. 548). Bireyin birey ile münasebeti hususi hukuk, devletin birey ile münasebeti ise amme hukuku kapsaminda değerlendirilmiştir (Veldet, 1940, s. 140). Devlete yönelik suç işleyen bireylerin sürgün yerleri genellikle Kıbrıs, Rodos, Girit gibi adalar arasından seçilmiştir. Bu gibi siyasi suçluların yaşam şartları zor ve ulaşım imkanları kısıtlı olan bölgelere gönderilerek siyasî meselelere müdahil olması engellenmek istenmiştir. 


\section{Kalebentlik Cezası}

Kale ve bend ${ }^{6}$ kelimelerinin birleştirilmesi ile oluşturulmuş olan kalebentlik kelimesi, kaleye bağlanmış anlamına gelmektedir. Terim olarak "Bir kalenin dahilinde serbest gezip ancak dişarısına çıkmamağa mahkûm kabahatli" anlamındadır (Sami, 1996, s. 1079). Ceza olarak ise suçlu bulunan şahsın, bir kaleye gönderilip, orada yaşamaya mahkûm edilmesi; kale içinde serbestçe gezebilme imkânına sahipken, dışarı ile irtibatına izin verilmemesi durumudur. Osmanlı ceza hukukuna özgü bir ceza şekli olan kalebentlik cezasına ta'zir cezası kategorisinde yer verilmiştir. Ticarî hayata hile karıştıran kimselere uygulanagelen bir ceza türü olduğunu ifade etmek mümkündür (Yurtseven, 2001, s. 286). Kalebentlik cezas1 alanların yeni bir suç işlemesi durumunda cezası küreğe çevrilmiştir (Avc1, 2004, s. 122). Kalebentlik cezasına 1858 Ceza Kanunnamesinde yer verildiği bilinmektedir. Bu kanunnamede cezanın muvakkat olma durumunda 3 yıldan 5 yıla, müebbet olma durumunda ise ölünceye dek ibaresine yer verilmiştir (Taner, 1941, s. 231). Hüküm tasdik olduktan sonra suçlu devletçe tayin olunan etrafı surlarla çevrili kaleleri olan şehirlere gönderilmiş ve burada cezasını çekmiştir. Mükerrer suçlarda suçlu daha önce hapis cezası alıp ıslah olmamış ise infazın tarzı ağırlaşıp, kalebentliğe dönüştürülmüştür (Akgündüz, 1989, s. 179).

Kalebentlik cezası alan suçlular prangaya vurulmamış, meşakkatli işlerde çalıştırılmamış, teşhir edilmemiş ve hatta hapsedilmemişlerdir. Kale içerisinde bir araya gelerek sohbet edebilmiş, ibadetlerini yapabilmiş, gündüz yanlarında memur bulunmak kaydıyla işlerini halledebilmiş ve hatta halk ile görüşüp konuşabilmiş; gece ise mutlaka kalede bulunmak üzere hapsedilmişlerdir (Gökçen, 1987, s. 61). Belgelerden elde edilen veriler sonucunda kalebentlik cezası gerektiren haller uygunsuz hareketler, serseri hareketler ve eşkıyalık suçları olarak tespit edilmiştir. Şahısların işlediği suçlar açık ve ayrıntılı surette anlatılmamış genel başlık altında verilmiştir. Bu nedenle suçun mahiyetine dair ayrıntılı bilgilere ulaşılamamıştır.

Kalebentlik cezasının dönemde kamu düzenini bozmaya yönelik eylemlere uygulandığ1 çıkarımına gidilmiştir. 1854 yılında Sayda valiliği Trablusşam sancağında Saftiya kazasında ortaya çıkan ihtilaldeki uygunsuz hareketler nedeniyle Nasiri Şeyhi Yunus zade Abdülhamit Trabzon'a kalebent olarak (İ.MVL, 311/12995), ve yine ayn yıl Selanik civarında serseri hareketler sergileyip nüfus katleden 10 kişinin yakalanarak Magosa'ya kalebent olarak (İ.MVL, 302/12336) gönderilmeleri meseleleri ile karşılaşılmıştır. Kalebentlik bölgeleri Trabzon, Trablus (İ.MSM, 72/2088) ve Magosa olarak tespit edilmiştir. Dönemde kısmî uygulama alanı bulan kalebentlik cezalarının, suçlunun nefsini ıslah ederek topluma kazandırılması düşüncesiyle tatbik edildiği anlaşılmaktadır. Bu ceza ile suçlu bulunduğu ortam ve bölgeden uzaklaştırılarak düşünmeye sevk edilmiş, iyi insan olmaya ve tekrar suç eylemine karışmamaya yönlendirilmiştir.

\section{Prangabentlik Cezası}

Pranga ve bend kelimelerinin birleştirilmesi sonucu oluşmuş olan ve "mücrimlerin ayağına vurulan zincirli halka" (Sami, 1996, s. 350) dolayısıyla prangaya vurulma anlamına gelen ifadedir. Suçlunun ayaklarına zincir bağlanarak infazının gerçekleştirildiği bir ceza türüdür. Kürek cezasının ilk uygulandığı dönemlerde mahkûmların ayağına pranga (halka) takılıp, bu halkaya zincir bağlanıp, bu zincir de ayağında pranga olan bir başka mahkûma

6 "1. Bağlama, rapt-1 kayd bend etmek: bağlamak, 2. Kendi hükmü altına alma, ayrılamayacak ve her hususta tabi olacak surette celb etme: kendine bend etmek ..." bknz. (Sami, 1996, s. 304). 
bağlamak sureti ile icra edilmiştir. Daha sonra prangabentlik tabirine dönüşmüş ve bu haliyle kullanılmaya devam etmiştir. Eski manası dikkate alınmadan suçlular için bir ceza şeklini almıştır (Gökçen, 1987, s. 54). Suçlunun ayağına vurulacak demir ile zincirin ağırlığı ve uzunluğu suçlunun cüssesiyle uyumlu olup hareket hakkını kısıtlamayacak şekilde olması, mahkûmların şahsi durumları göz önüne alınarak muamele yapılması ve özel işlerde çalıştırılmamaları karara bağlanmıştır. 1869 Ceza Kanunnamesi ile daha sonraki kanunnamelerde prangabentlik cezası alan suçluların ağır maden işlerinde çalıştırılması, bu işlerde çalışanlara ücret ödenmesi, ihtiyaçları kadarının kendilerine verilmesi, borçları varsa kalan miktardan borçlarının ödenmesi ve yine kalan miktar olur ise tahliye anında kendilerine ödenmesi kararlaştırılmıştır (Cin \& Akgündüz, 1990, s. 336).

Prangabentlik cezasının hangi durumlarda uygulandığı, ağır cezalar içerisindeki yeri ve Abdülmecid döneminde bu cezaya hangi sıklıkla başvurulduğu meseleleri diğer araştırma sorularıdır. 1840 Ceza Kanunnamesi 2/1-2 maddelerinde bir şahsın bir başka şahıs ya da şahısları devletin kanun ve nizamlarına aykırı harekete sevk edecek sözler söyleyecek olur ise suçunun derecesine göre 1 seneden 5 seneye kadar vaz-ı kürek ve yine insanları isyana sevk etmek için onlara silah ve barut verip siyaseten katl eylemine karışıldığ takdirde ise müebbeden kürek cezasının tatbik edileceği kararlaştırılmıştır (Kaynar, 2010, s. 304). Sarkıntılık, sarhoşluk ve kumarbazlık suçlarından iki defadan fazla mahkûm olanlara cürümde ısrar etmiş sayılacağından, nedamet ve tövbeleri hasıl oluncaya kadar Dersaadet'te ise kürek, taşrada ise prangabentlik cezasının verilmesi uygun bulunmuştur (Avc1, 2002, s. 140). Bu maddeden hareketle Tanzimat döneminde suçun mahiyeti ve kürek cezasından ayrıldığı temel nokta net bir şekilde belirtilmiş ve her iki ceza birbirinden ayrılmıştır. Prangabentlik cezasına neden olan haller mahkûmlara işkence yapılması, konsoloshane baskını, eşine zulüm etmek, yardım ve yataklık, itaatsizlik suçları olarak karşımıza çıkmıştır. Kalebentlik cezasında olduğu gibi prangabentlik cezasının da kısmî bir uygulama alanı bulduğu anlaşılmaktadır.

1847 yılında mahkûmlara işkence edilmesi ile birlikte Yanya'daki Fransa konsoloshanesine gerçekleştirilen baskında yapılan soruşturma ve sorgulamaların sonucunca elebaşı olduğu tespit edilen kethüda Zeki Efendi'nin Kıbrıs'a prangabent olarak ve yine parmağı bulunan Vehib Efendi'nin Selanik'e ve Süleyman Ağa'nın ise İzmir'e sürgüne gönderilmeleri (İ.MSM, 28/775) meselesi karşımıza çıkmıştır. Bu olayda girift bir mesele ile karşılaşılmış ve birden fazla suç tespiti yapılmıştır. Burada sadece elebaşı olduğu gerekçesi ile Zeki Efendi'ye prangabentlik cezası verilirken diğerlerine sürgün cezası verildiği tespit edilmiştir. Yardım ve yataklık meselesinin de prangabentlik cezasına neden olduğu anlaşılmaktadır. Bununla alakalı olarak 1848 yılında Duçek Kürtleri reisi olup Vidin'e sürgüne gönderilmekte olan Mustafa Bey'in, Boğaziçi'nde bindirilmiş olduğu gemiden firar etmesine yardım eden Kabakçı Mustafa'nın 6 ay müddetle prangabentlik cezasına çarptırılması (A.MKT.MVL, 11/68) meselesi ile karşılaşılmıştır.

Cürümde ısrar etmek Dersaadet'te kürek, taşrada ise prangabentlik cezasına neden olmuştur. Bu noktadan hareketle suç eyleminde ısrarcı olma meselesinin bu cezanın ayırıcı vasfı olduğu çıkarımına gidilmiştir. Eşine zulüm ettiği için Sivas'tan Bolu'ya sürgüne gönderilmiş olan Celal Bey'in fiilinde ısrarcı olması 1850 yılında ceza türünün prangabent olarak değiştirilmesine (A.MKT.UM, 29/56) neden olmuştur. Muvakkat prangabentlik cezası alan suçluların ceza sürelerini tamamlamaları halinde tahliye olunabilmek için kefil göstermeleri gerekmiştir. 1851 Ceza Kanunnamesi 3/13 maddesinde bu hükme "1 sene müddetle nefy ve tağrib ve prangabent olunup eğerçi, bu misilli eşhas müddet-i merkume

SEFAD, 2020; (43): 497-518 
içinde 1slah-1 nefs edip kendisinden emniyet hasıl ettirerek ahaliden kefil verebilirse sebili tahliye..." ifadeleri ile yer verilmiştir (Avc1, 2002, s. 132). Bu şartı yerine getiremeyen suçlular 1slah-1 nefs etmiş olsa dahi kefil belirtene kadar tahliye edilmemiştir.

\section{Kürek Cezası}

Osmanlı Devleti'nin 16. yüzyıl ile 18. yüzyıl arasında en çok uygulandığı ağır cezalardan biri de kürek cezası olmuştur. Daha çok toplumun huzurunu bozan, İstanbul'da başıboş dolaşan, İstanbul'a gelip kötü işler yapan şahıslara ve görevini kötüye kullanan memurlara verilmiştir (Yurtseven, 2001， s. 285). Gemilerde kürek çektirmek suretiyle uygulanan bir ceza olup, hapisten daha ağır bir ceza olarak karşımıza çıkmıstır (Avcl, 2002, s. 138). 1851 Ceza Kanunnamesi 1/14 maddesine göre; suçluların ayaklarında demir (pranga) olduğu halde meşakkatli işlerde kullanılmak sureti ile cezasını çekmesi durumu olarak tanımlanmıştır (Cin \& Akgündüz, 1990, s. 336). Diğer ağır cezalarda olduğu gibi kürek cezası da hem muvakkat hem de müebbet olarak uygulanmıştır. Müebbet olduğu takdirde suçlu, vefat edinceye kadar, süreli olduğu takdirde ise 3 yıldan 15 yıla kadar verilmiştir. Suçlular devlet tarafından tayin edilen yerlerde gücü nispetinde zor işlerde çalıştırılmıştır. Cezanın infazı sırasında suçluların medeni haklarını kullanması yasaklanmış ve ceza süresi tamamlanana dek işlerini yürütmek üzere kendisine vasi de tayin edilmiştir (Gökçen, 1987, s. 53-56).

Kürek cezasına neden olan halleri ortaya çıkarmak ve suçluların ceza sürelerini tespit etmek diğer son araştırma sorusunu oluşturmaktadır. Kürek cezası ile alakalı sadece iki mesele karşımıza çıkmıştır. Bunlardan ilki 2 Ocak 1847 tarihinde Erzurum'da İran tebaasından olan Mirza Hasan ile birkaç nefer acemin katli meselesi ile alakalı yakalanan üç kişinin Tersane-i Amire'de 7 'şer sene müddetle kürek cezasına çarptırılması (İ.MSM, 82/2343) meselesidir. 5 Ağustos 1847 tarihinde 1slah-1 nefs ettikleri düşünülerek kürek cezalarına son verilmiş ve sürgüne gönderilmeleri (İ.MSM, 82/2345) kararlaştırılmıştır. Dolayısıyla kürek cezası süresinin 8 ay kadar sürdüğü ve ıllah-ı nefs gerekçesi ile cezalarının sürgüne çevrildiği tespit edilmiştir. Karşlaşılan diğer mesele ise Mart 1844 tarihinde Arnavut eşkıyasından olan Mehmet Salih'in 5 sene, Bahti Bey'in ise müebbet olarak Tersanei Amire'de kürek cezasına çarptırılmalarıdır. Ceza çekerken ıslah-1 nefs etmiş oldukları düşünüldüğünden Bursa yönüne nakilleri istenmiş, fakat Kasım 1847 tarihinde Bursa yerine Trablusgarp tarafına gönderilmeyi talep etmişlerdir (A.MKT, 101/88). Bu meselede ceza süresinin 3 yıl 8 ay kadar sürdüğü anlaşılmaktadır. Kürek cezasına sebep olan haller katl ve eşkıyalık meseleleri olarak karşımıza çıkmıştır.

Kürek cezasına mahkûm olanların ayaklarına bağlanacak demir ve zincirlerin suçluların hareket kabiliyetini engellemeyecek şekilde olmasına, çalışılan iş neticesinde suçlulara belli bir miktar ücret ödenmesine karar verilmiştir. Fakat ücret ödemelerinin firara neden olmaması için tahliye durumlarında yapılması uygun bulunmuştur (Gökçen, 1987, s. 55-56). Kürek cezasına çarptırılan suçlular aileleri sefalete düştügüunde evlerinde edepleriyle meşgul olarak ömürlerini tamamlamak şartı ile salıverilmiştir (Kankal, 1987, s. 199).

\section{B. Cezanın Kesinleştirilerek İnfazın Gerçekleşmesi}

Cezanın kesinleştirilerek infazın gerçekleşmesi meselesi araştırmanın ikinci temel ayağını oluşturmaktadır. Abdülmecid döneminde Tanzimat'ın ilanı ile birlikte yeni bir hukuk sistemine geçiş süreci yaşanmıştır. Bu yeni sistem ile kanunlara aykırı hareket eden yani yasaları çiğneyen suçlular ile toplumdaki bireylere zarar verici davranış gösteren yani toplumsal huzuru bozan suçlular birbirinden farklı şekillerde değerlendirilmiştir. Kanunlara 
aykırı hareket eden suçlulara topluma verdiği zararın büyüklüğü nispetinde ıslah olmayacağı kanaati uyandırıyor ise idam cezaları, toplumdaki bireylere zarar verici davranış gösteren suçlulara ıslah olacağı kanaati uyandırıyor ise sürgün, kalebent, prangabent ve kürek cezaları verilmiştir.

Cezaların kesinleştirilmesi hukukî ve idarî bir süreç sonunda gerçekleştirilmiştir. Öncelikle şahıslar hakkında yerel mahkemeye şikâyette bulunulmuş, ardından yargılama süreci başlatılmıştır. Kadı, şahitler ve deliller sonucunda kararını vermiş; suçun sabit olması durumunda mahkûmun cezalandırılması için ilamı merkeze göndermiştir. Kadılar, ilamda suçlu bulunan kişinin ne şekilde cezalandırılması gerektiğine dair tavsiyede bulunmuş; merkez ise genellikle kadının tavsiyesini göz önünde bulundurarak olayı inceledikten sonra cezayı kesinleştirmiştir (Baytimur, 2011, s. 3). Diğer bir yol da şikayetlerin doğrudan merkeze yapıldığı, ardından yargılamanın başlatıldığı süreçtir. Bu kez de suçun işlendiği ya da suçlunun bulunduğu yerdeki ilgili yerel merciler merkez tarafından haberdar edilip; olayın soruşturulması talep edilmiştir. Bu gibi hallerde soruşturmanın gizlilikle ve suçlunun statüsü dikkate alınarak yürütülmesi önem arz etmiştir (Köksal, 2006, s. 291).

Tanzimat'ın ilanından itibaren yargılama görevini Meclis-i Vâlâ-yı Ahkâm-ı Adliye üstlenmiştir. Mecliste kanun ve yasalara aykırı davranan idareci ve devlet adamları da cezalandırılmıştır (Akyıldız, 1993, s. 197). Üst düzey devlet adamları ağır cezalara çarptırıldığı taktirde onları menfalarına ulaştırma görevi çavuşlara, kavvaslara ve gerekli hallerde ise zaptiyelere verilmiştir. 1854 yılında Harput Eyaleti'nde eski müftü Hacı Şakir Efendi ve eski Vali Hamdi Paşa'nın ekibi ile birlikte halkı rencide edip, karyede düzeni sağlayamaması sonucu yargılanıp Sivas'a sürgüne gönderilmeleri (İ.MVL, 309/12843) meselesinde mübaşir olarak Molla Mehmet, Selim kavvas ve 12 nefer zaptiyenin de görevlendirilmesi bunu kanitlamaktadır.

Sürgün ya da diğer ceza istekleri sadrazama, onun yokluğunda sadaret kaymakamına sunulmuş, bunlar tarafından da padişaha arz edilmiştir. Kararın kesinleşmesi padişahın takdirine bırakılmıştır. Padişah onayı alındıktan sonra ferman tanzim edilerek, suçluya tebliğ edilmiş, mahalline götürmek üzere mübaşir adı verilen divan-ı hümayun çavuşu görevlendirilmiş ve ferman ona teslim edilmiştir (Alan, 2014, s. 261). Görevlendirilen memurların masrafları devlet tarafından karşılanmıştır. Bunu, 1847 yılında Ayvalık'ta meydana gelen kargaşada parmağı olarak yakalanan birkaç kocabaşı menfalarına götürmek üzere mübaşir olarak görevlendirilen Selami Efendi ve 5 kavvasın harcırah bedelinin ise 7500 kuruş olarak belirlenmesi meselesinde (İ.MSM 83/2361) de anlayabilmek mümkündür. Suçluların devlete ödemek zorunda olduğu borçlar ile ilgili mal tespiti yapmak için mübaşir tayini de yapılabilmiştir. 1853 yılında Sarıkeçili ve Denizli aşiretlerinin emval-i mirîye mültezimi olup, 6 ay müddetle Silifke'ye sürgüne gönderilen Isparta hanedanından Hacı Ethemzade Elhac Ali Ağa'nın 1852 yılı mirî mal tespiti için tayin edilen mübaşirin Burdur'a gönderilmesi (İ.MVL 288/11463) bunu kanıtlamaktadır. Suçluların mallarını, sürgüne gönderilmeden önce müsadere edilmesi gerektiği durumlarda da yine müsadere memurları görevlendirilmiştir. Bu memur, suçlunun mallarını titiz bir şekilde araştırıp soruşturmuş ve devlet adına deftere kaydetmiştir (Köksal, 2006, s. 297). Bu gibi hallerde suçlunun tedbir alma, kaçma, isyan etme gibi riskli durumları yüzünden görevin büyük bir gizlilik içinde yürütülmesine önem verilmiştir.

SEFAD, 2020; (43): 497-518 


\section{Cezanın Sona Ermesi}

Araştırmanın üçüncü ve son temel ayağını cezaların sona ermesinde nasıl bir sürecin izlendiği meselesi oluşturmuştur. Hangi durumlarda cezaların sona erdirildiği, hangi durumlarda cezaî indirim yapıldığı ve af durumları yanıtlarını aradığımız sorulardandır. Karşılaştığımız ağır cezaları genel olarak iki şekilde tasnif etmek mümkündür. Bunlardan ilki ömür boyu olan cezalar, diğeri ise süreli olan cezalardır. Süreli cezalardaki amaç, suçlunun nefsini ıslah etmesini sağlayarak topluma yeniden kazandırılmasını sağlayabilme düşüncesidir. Islah-1 nefs ibaresinden yola çıkarak tek tip bir ceza uygulamasından bahsetmenin mümkün olmadığı sonucuna ulaşılmıştır. Çünkü nefsini ıslah etmek kişiden kişiye değişkenlik arz eden bir süreçtir. Bu nedenle belirlenen süreden önce ya da sonra cezalar sona erdirilebilmiştir. Özel durumlarda suçluların af talebinde bulunabildikleri de tespit edilmiştir. Af taleplerinin kabul edilebilmesi için ceza süresinin yarısının tamamlanması şartı aranmıştır. 1853 yılında Çankırı'dan Ankara'ya iki yılllı̆ı̆na sürgüne gönderilen Hacı Musa, Salih ve Ali Efendilerin müddetleri dolmadığı halde ceza süresinin yarısın tamamlayıp, 1slah-1 nefs ettiklerini bildirerek af talep etmeleri (İ.MVL, 289/11521) bunu teyit etmektedir.

Ağır ceza kararlarını onama yetkisinde olduğu gibi af ve ıtlak taleplerinde de onama yetkisi padişaha aittir. Bu nedenle talepler bizzat padişaha yapılmıştır. Hokand elçisinin Der-saadet'e gelirken yol esnasında Sungur kazası ayanı Emin Bey'i şikâyet etmesi sonucu, Emin Bey'in Karahisar-1 Sahip'e sürgüne gönderilmesi meselesinde padişahtan bizzat af talebinde bulunduğu anlaşılmaktadır. Af mektubundan suçlunun Dersaadet'e gelmesinin yasaklandığını ve ayanlıktan azledildiğini anlamak mümkündür. Af gerekçesi olarak evlad $\mathrm{u}$ ıyalinin (eş ve çocuklarının) perişanlığını ifade ettiği anlaşılmaktadır. Talebini içeren af mektubu kısaca şu şekildedir: Hizmette kusur ettiğimiz için çok pişman olduk. Islah-1 nefs edip Der-saadet'e gelmemiz men edilmiş, yasaklanmış ve ayanlıktan azl edilmiş olup, evladımızdan ayrılıp Karahisar-ı Sahip'e sürgüne gönderildik. Hata yapmak küçüklerden, affetmek büyüklerden. Islah-ı nefs ettiğimden affımı talep edip, eş ve çocuklarımı sevindirmenizi niyaz ederim (HAT, 472/23).

Cezaların süresi içinde çekilip tamamlandıktan sonra suçlunun itlak edilmesi cezaların normal tamamlanma sürecidir. Genel ya da özel af durumları ile de cezalar sonlandırılabilmiştir (Uluçay, 1951, s. 537-547). Genel af durumları özel günler7, sevindirici haberler, kuvvetli askeri, siyasi, sosyo-ekonomik çalkantılara neden olan savaşlar, iç karışıklıklardır. Özel af durumunun ilki bireysel af iken, diğeri ise cezanın hafifletilmesi durumudur (Köksal, 2006, s. 301-303). Af durumlarına neden olan haller iyi hal sergilemek, perişanlığını bildirmek, menfasının havasına alışamamak, eş ve çocukların mağduriyeti, yaşlılık ve hastalık ile geçinememe olarak tespit edilmiştir.

Af başvuruları genellikle geri çevrilmemiştir. Af talepleri için çeşitli gerekçeler öne sürülmüştür. Bu gerekçelerden ilki, iyi hal sergilemek suretiyle af talep etme meselesidir. Talepler menfiler, yerel yöneticiler ya da bölge halkı tarafından merkeze bildirilmek sureti ile yapılmıştır. 1848 yılında Kayseri'deki Dergâh-ı Ali kapıcıbaşılarından olup, Bolu'ya sürgüne gönderilen Salih Ağa zade Hacı Mehmet Ağa'nın iyi hal sahibi olduğu ve sürgünde olmasının haksızlık olduğu gerekçesi ile bölge İslam halkı tarafından merkeze bildirilen af talebidir (A.DVN, 40/16). Perişanlığını bildirmek suretiyle de af talebine rastlanmıştır. 1853

\footnotetext{
7 Padişahların tahta çıkışları (cülus) ya da cülus yıldönümleri nedeniyle bu gibi aflar ilan edilmiştir. Bkz (Köksal,
} 2006, s. 301). 
yılında Bosna meselesinden dolayı Bursa'ya sürgüne gönderilen Bihkeli Mehmet, Saraylı Fazıl Paşa ile Madenli Derviş Bey'in kimi yalnız kimi eş ve çocukları ile sürgüne gönderilmiş olup, sürgünde iken maaş alamamaları yüzünden perişanlıklarını bildirip af talep etmişlerdir (İ.MVL, 288/11443). Menfasının havasına alışamamak sureti de diğer bir talep sebebidir. 1853 yılında Karahisar'dan Denizli'ye sürgüne gönderilen Rikab-1 Hümayun kapıcıbaşılarından Ali Bey'in, Denizli'de 3-4 ay kaldıktan sonra bölgenin havasına alışamayıp, hastalığa yakalanması gerekçesi ile affını talep etmesi (İ.MVL, 289/11514) ve hastalığına binaen ceza müddeti kâfi görülerek af ve itlakına onay verilmesi meselesi ile karşılaşılmıştır. Eş ve çocukların mağduriyetini bildirmek sureti de diğer bir gerekçedir. Bu gibi durumlarda arzuhaller genellikle geri çevrilmemiştir. Bunun temel sebebini aile bütünlüğünün zarar görmemesi olarak değerlendirmek mümkündür. Bununla alakalı olarak 1839 yılında Midilli'de sürgünde olan Miralay Musa Bey'in eş ve çocuklarının sefalet içinde kalması üzerine tekrar askerlik mesleğine dönmemek üzere affedilmesi (C.AS, 204/8744) ve 1847 yılında Denizli'de sürgünde bulunan Hayriye tüccarlarından İzmirli Hacı Mustafa Efendi'nin eş ve çocukları sefalet içinde bulunduğundan affedilmesi (A.MKT, 66/72) meseleleri ile karşılaşılmıştır. Yaşlılık nedeniyle de af talebinde bulunulmuştur. 1853 yılında Tokat'tan Sivas'a sürgüne gönderilen sandık emini Abdullah Efendi'nin 90 yaşında olup, ihtiyarlı̆̆1 nedeniyle (İ.MVL, 290/11562) ve 1859 yılında Musul'dan İmadiye'ye sürgüne gönderilen Bohtan'ın ihtiyarlığı nedeniyle affını talep etmesi (A.MKT.MHM, 150/67) bunu kanıtlamaktadır. Hastalık da bir diğer talep nedenidir. Aile fertlerinden birinin hastalığı, bakacak kimsesinin olmadığını bildirmesi talebin kabul edilmesinin temel şartıdır. 1840 yılında Balisyos adlı rahibin azlolunduktan sonra garaz ve intikam hissi nedeniyle Kıbrıs, Tur-i Sina ve Sakız'a ardı ardına sürgüne gönderilmişken, annesinin hastalığını ve oğlunun bakımına muhtaç olduğunu bilmesi üzerine, İstanbul'a gelmesi yasak olduğu halde, hanesinden çıkmamak üzere annesinin bakımı ile ilgilenmesi için onay verilmesi (C.ADL, 85/5122) karşımıza çıkmıştır. Suçluların ya da ailelerinin geçinemediğini bildirmesi üzerine de af talebinde bulunulduğu da tespit edilmiştir. Bu gibi hallerde günlük yevmiye miktarı tayin edilerek sıkıntılar giderilmeye çalışılmıştır. 1850 yılında İstanbul'a ayak basmamak üzere Trabzon'a sürgüne gönderilen Priştineli Ahmet Efendi geçinemeyip sıkıntı yaşadığını belirterek affını talep etmiş ve bunun üzerine 30 kuruş yevmiye tayin edilmiştir (A.AMD, 21/59). 1853 yılında da Ohri sancağı Tiran kazasından Hadim kazasına sürgüne gönderilen Şeyh Süleyman Efendi 1 seneyi aşkın süredir sürgünde olup hiçbir geliri olmadığını belirterek affını talep etmiştir (İ.MVL, 293/11784). Af talebinde bulunabilmek için ceza sürelerinin yarısını tamamlamış olmak şartı ve cezanın sona erdirilmesi için ise ıslah-ı nefs etme şartı aranmıştır.

Gayrimüslimlerin af taleplerinin patrikhane tarafından merkeze bildirildiği görülmüştür. Bununla alakalı olarak 1847 yılında İzmit sancağına bağlı Korin karyesinden Küçük Çekmece'ye sürgüne gönderilen Vaham adlı rahibin eş ve çocuklarının sefil ve perişanlığını belirtmesi sureti ile affını talep etmesi ve patrikhanenin kefaleti ile serbest birakılması (A.DVN, 22/88) ve 1848 yılında Bulgar taifesinden olup Aynaroz adasindaki Hilandar manastırına sürgüne gönderilen İlaryon adlı rahibin patrikhane aracıllğı ile pişmanlığını bildirerek affını talep etmesi (A.DVN, 42/10) bunu doğrulamaktadır.

Cezanın hafifletilmesi isteği ya da af talepleri suçlular, yerel yöneticiler tarafından yapılabildiği gibi geride kalan aileler ya da memleketindeki veya menfasındaki ileri gelenler tarafından da yapılabilmiştir (Alan, 2014, 265). Bunu 1840 yılında Konya müşiri Hacı Ali Paşa'nın Nevşehir ahalisinden olup Ankara ve çeşitli mahallere sürgüne gönderilen 4 
suçlunun ceza sürelerini tamamlayıp üzerinden de hayli zaman geçtiği halde salıverilmelerine izin verilmediği, memleketlerinde eş ve çocuklarının sefalet içinde kaldığı, kendilerinin de sslah-1 nefs etmiş olduğu, af ve ttlaklarına izin verilmesi için irade gönderilmesini talep ettiği (HAT, 1424/58257) meselesinden de anlayabilmek mümkündür. Konya müşiri Hacı Ali Paşa'nın menfilerle alakalı af talebini merkeze ilettiği anlaşılmaktadır.

Ceza bittiğinde resmi bir yazışma süreci takip edilmiş ve ardından suçlular serbest bırakılmıştır. Yazışma süreci uzadığından suçluların salıverilme süreci de uzayabilmiştir. Bunu 1844 yılında Aynaroz'a sürgüne gönderilen Rum ruhbanlarından Yerasimos, Sirozlu İsa ve Bağdatlı Süryani Oseb adlı rahiplerin ceza sürelerini tamamlayıp, üzerinden zaman da geçmiş olduğu halde irade gönderilmediği için bekletilmeleri (C.ADL, 16/982) ve 1859 yılında Kıbrıs'a sürgüne gönderilen Ali ve Ahmet Beylerin ceza sürelerini tamamladıktan sonra istedikleri mahalle gönderilmeleri için izin talep ettikleri halde ruhsat verilmediği için bekletilmeleri (A.MKT.MHM, 150/76) meseleleri ile açıklamak mümkündür. Dolayısıyla ceza süresi tamamlansa dahi menfilerin ıtlakına dair merkezden hüküm gönderilmeden suçluların salıverilmediği çıkarımına gidilmiştir.

\section{SONUÇ}

Osmanlı Devleti'ndeki ta'zir ceza grubu içerisinde yer alan ağır ceza kategorisindeki sürgün, kalebent, prangabent ve kürek cezaları Abdülmecid dönemi ekseninde incelenmiştir. Bu cezalar temel olarak iki ana kategoride toplanmıştır. Bunlar; hürriyet kısıtlayıcı rolü ile sürgün ve kalebent, hürriyet bağlayıcı rolü ile prangabent ve kürek cezalarıdır. Ağır ceza kategorisi içerisinde yer alan sürgün ve kalebent cezalarına nispetle prangabent ve kürek cezalarının daha ağır cezalar olduğu tespit edilmiştir.

Sürgün cezasının en çok başvurulan ceza grubu olarak öne çıktığı, fakat diğerlerine nispetle daha hafif bir ceza türü olduğu anlaşılmıştır. Dönemde sürgün cezasına sebep olan haller olarak; Tanzimat'a yönelik isyan girişimleri, kendi halinde olmamak, fitne ve fesat olmak, düzeni bozmak, eşkıyalık, halkı kışkırtmak, firar, rüşvet, iftira atmak, ahaliden zorla para almak, alacağından fazla para talep etmek, katl, haneye tecavüz, ırza tecavüz, hakaret ve küfür, yardım ve yataklık, cemaat ile iyi geçinmemek, hırsızlık, resmi evrakta sahtecilik gibi suçların ve kalebentlik cezasına sebep olan haller olarak ise; uygunsuz hareketler, serseri hareketler ve eşkıyalık suçlarının sebep olduğu bulgularına ulaşılmıştır. Suç derecelerinin hafif olduğu durumlarda, ceza süreleri kısa tutulup yakın bölgeler tercih edilmiş; suç dereceleri ağırlaştığında ise ceza süreleri uzayıp ceza bölgelerinin de uzaklaştığı tespit edilmiştir. Sürgün ve kalebentlik cezaları alan suçluların gönderildikleri bölge ya da kale sınırları içerisinde serbestçe yaşama olanağı bulduğu anlaşılmıştır. Ailelerle birlikte yapılan sürgünlere de rastlanmıştır. Geride kalan eş ve çocukların sefalete düşmesini engellemek ve suçluların kaçma ihtimalini azaltmak için bu uygulamaya başvurulduğu çıarımına gidilmiştir. Yine ailelerin mağduriyetini engellemek amacıyla suçlular cezaî indirime tabi tutulmuş ya da af edilmiştir. Bu noktadan hareketle aile bütünlügüne önem verildiği çıkarımına gidilmiştir. Toplu af uygulamasına dair herhangi bir veriye ulaşılamamıştır.

Tanzimat döneminin eşitlik ilkesinden hareketle cezalar verilirken herhangi bir dini ayrıma gidilmemiştir. Dini cemaat liderlerine de cemaati üzerinde sürgün cezası uygulama yetkisi tanınmıştır. Gayrimüslimlerin af taleplerine dair yazışmaların da patrikhane aracılığıyla yürütüldüğü tespit edilmiştir. 
Prangabent ve kürek cezaları alan suçlular ise devletçe belirlenen ağır işlerde çalıştııılmışlardır. Çalışmaları karşılığında ücret elde edebilmişlerdir. Prangabentlik cezalarına mahkumlara işkence yapılması ile konsoloshane baskını, eşine zulüm etmek, yardım ve yataklık ile itaatsizlik suçlarının; kürek cezalarına ise katl ve eşkıyalık suçlarının sebep olduğu tespit edilmiştir. Bu iki ceza grubunda da suçluların salıverilmesi için kefalet şartı aranmış ve bu şartı yerine getirmeyen mahkumların serbest bırakılmadığı tespit edilmiştir.

Mükerrer sürgün bölgelerinin varlığı, devletin sistemsel bir düzen doğrultusunda ceza politikası yürüttüğünü ortaya koymuştur. Ağır ceza hareketliliğinin yoğunluklu olarak Anadolu coğrafyası ekseninde yapıldığı tespit edilmiştir. Kıbrıs'ın sekiz sürgün ile başı çeken bölge olduğu verisine ulaşılmıştır.

Ağır ceza uygulamaları ile suçluların bulundukları bölgeden uzaklaştırılarak düşünmeye sevk edilmesi, yeniden suç eylemine karşımalarının engellemesi, cezaî yaptırım nedeniyle aynı suçun başkaları tarafından ifa edilmesinin önüne geçilmesi, suçluların topluma yeniden kazandırılması ve toplumsal istikrarın korunması gibi düşüncelerin amaçlandığı anlaşılmaktadır. Fakat cezalar bütün mahkumları uslandırmamıştır. Bazen ceza süresi içerisinde bazen de ceza bitiminde suçluların yeniden suç eylemine karıştı̆̆ tespit edilmiştir. Suçluların ceza bölgelerine gönderilmesi nedeniyle ortaya çıkan masraflar Maliye Nezareti'nden Zaptiye Nezareti'ne havale edilerek gerçekleştirilmiştir. Devlet memurlarının cezalandırılması durumunda konumuna binaen yeterli sayıda mübaşir ile kavvas adı verilen silahlı çavuş da görevlendirilerek, suçlunun güvenli bir şekilde ceza bölgesine ulaştırılmaya çalışıldığı tespit edilmiştir.

Cezalandırılma bölgelerinde zorunlu hallerde değişiklik yapılabildiği de tespit edilmiştir. Ceza süreleri tamamlansa dahi merkezden itlak hükmü gönderilmeden suçluların salıverilmediği anlaşılmaktadır. Çalışmada dikkat çeken diğer önemli bulgu ise döneme ait belgelerde kadınlarla ilgili kayıtlara rastlanmamasıdır. Bu durum daha sonra yapılacak olan çalışmalarda ayrıca araştırılması gereken bir sonuç olarak karşımıza çıkmıştır.

\section{SUMMARY}

This study examines the liberty binding and limiting penalties imposed during the reign of Abdülmecid. The Ottoman State was a state governed by Islamic law and evaluated heavy penalties in the ta'zir category. With radical and significant steps taken during the Tanzimat period, the state adopted a new understanding of law and published criminal codes. In published legislations, exile, fortress, shackles and penal servitudes are included in the category of heavy penalties. The subject of the study involves exile and fortress as liberty restrictive penalties, and shackles and penal servitudes as liberty limiting penalties. Depending on the degree of harm inflicted on the society, criminals who violated the law were sentenced to death if the offender's behavior did not indicate potential improvement, while the less serious offenders were sentenced to exile, fortress, shackles and penal servitudes if their behavior indicated potential improvement. The state imposed different penalties for the individual's crimes against the individual and against the society and the state. The offenders who impaired social stability were kept away from their region and forced to think. All of these punishments included relocation. It is possible to say that among the harsh punishments administered during the reign of Abdülmecid, exile was the most extensively imposed punishment. The underlying mechanisms behind exile were classified as rebellion attempts against Tanzimat, hostile behavior, mischief, disruption of order,

SEFAD, 2020; (43): 497-518 
banditry, provocation of the public, escape, bribe, slander, racketeering, massacring, housebreaking, rape, insult and swearing, help and abetting, not getting along well with the community, theft, and forgery of official documents, while the reasons for fortress penalty were classified as improper behavior, bum movements and banditry. Not only criminals sentenced to exile were able to live freely within the borders of the region in which they were sent, but also criminals who received fortress penalty were able to freely live within the boundaries of castle where they were sent. Sometimes the exile was made with the criminals family. Correspondence regarding the amnesty demands of non-Muslims was carried out though the patriarchate. Exile mobility was mostly carried out in the Anatolian region. Political criminals were sent to the islands with difficult living conditions and limited access. Repetition of crime is the base of the aggravation of execution. If a criminal who was sentenced to prison did not improve, his execution was aggravated and his sentence was turned into a fortress penalty. Those convicted more than twice for offences including molesting, drinking and gambling were considered to insist in crime and therefore sentenced to penal servitudes in Dersaadet and shackles in the countryside until they repented. Criminals who were punished with shackles and penal servitudes were forced to work in heavy and mining jobs and deserved a wage in return for their labour. The reasons for shackling were classified as torture of prisoners, consular raid, cruelty to wife, help and abetting, and disobedience, while the reasons for penal servitudes included massacring and banditry. It was found that they received only as much as they needed, and if they had debts, their debts were paid from the remaining amount, and if any, the remaining money was given at the time of release. In both these criminal groups, bail was sought for the release of the criminals. It was determined that the prisoners who did not fulfill the bail requirement were not released. The subject period witnessed special amnesty cases, but there is no information regarding general amnesty implementations. The penalty areas were subject to change. It was aimed for removal of criminals from their region and referring them to think, preventing them from re-criminaling, preventing the same crime from being executed by others, regaining criminals to society and maintaining social stability. However, it seems that the penalties were not enough to settle down all prisoners as it was determined that they were involved in the crime action again, sometimes during the sencence, and sometimes after they were released. It was also determined that it was necessary to make some amendments in mandatory situations. For example, some criminals were not released without the approval of the center even if they had completed their sentences. The existence of repeating exile areas shows that a systematic exile policy was followed. Another notable finding in the study is that there is no recorded information about women in the documents during this period. This situation appears as a result that should be investigated further in the future studies. 


\section{KAYNAKÇA}

\section{Arşiv vesikaları}

BOA (T.C. Cumhurbaşkanlığ

A.AMD (Amedi Kalemi Evrak1) 21/59; 28/18.

A.MKT (Mektubi Kalemi Evrakı)

$66 / 72 ; 101 / 88 ; 103 / 80$.

A.MKT.MHM (Mühimme Kalemi Evrakı) 150/4; 150/67; 150/76; 164/56; 175/4.
A.MKT.MVL (Meclis-i Vala Evrakı) 11/68; 19/80.
A.MKT.UM (Umum Vilayat Evrak1) 29/56.
C.ADL (Cevdet Adliye Evrak1) 16/982; 85/5122.
C.AS (Cevdet Askeriye Evrak1) 204/88744.

HAT (Hatt-1 Hümayun Tasnifi) 453/22439; 472/23; 1424/58257.

İ.DH (İradeler, Dahiliye) 82/4134; 172/9205; 264/16477; 457/30321; 479/32190.

MVL (Meclis-i Vala Riyaseti) 928/31

İ.MVL (Meclis-i Vala Evrak1) ７6/2175; 288/11443; 288/11463; $289 / 11514 ; \quad 289 / 11521$; 290/11562; 290/11568; 293/11784; 293/11785; 302/12336; 302/12370; 303/12409; 303/12447; 309/12843; 311/12995; 396/17231.

A.DVN (Divan Kalemi Evrakı) 3/77; 22/88; 26/90; 32/8; 40/16; 42/10; 51/7.

İ.MSM (İradeler, Mesail-i Mühimme) 28/775; 66/1896; 72/2088; 82/2345; 83/2361.

\section{Telif ve Tetkik Eserler}

Acehan, A. (2008). Osmanlı Devleti'nin sürgün politikası ve sürgün yerleri. Uluslararası Sosyal Araştırmalar Dergisi I, (5), 12-29.

Akgündüz, A. (1989). Şer'iye Sicilleri: Mahiyeti, Toplu Kataloğu ve Seçme Hükümler. İstanbul: Türk Dünyası Araştırmaları Vakfı Yayınları.

Akgündüz, A. (1990). Osmanl Kanunnameleri ve Hukuki Tahlilleri. İstanbul: Fey Vakf1 Yayınları.

Akyıldız, A. (1993). Tanzimat Dönemi Osmanlı Merkez Teşkilatında Reform. İstanbul: Eren Yayıncilik.

Alan, G. (2014). 19. yüzyılda Osmanlı'da sürgün politikası çerçevesinde sürgün kadınlar. Belleten LXXVIII, (281), 245-272.

Avcı, M. (2002). Osmanlı uygulamasında infazı özellik gösteren hapis türleri: kalebentlik, kürek ve prangabentlik, Yeni Türkiye: Türkoloji ve Türk Tarihi. VIII, (45), 128-147.

Avcı, M. (2004). Osmanlı infaz hukukundaki gelişmelere genel bir bakış. Selçuk Üniversitesi Hukuk Fakültesi Dergisi XII, (3-4), 87-159.

Baytimur, S. O. (2011). Osmanlı Devleti'nde Hapis ve Sürgün Cezaları (Basılmamış Doktora Tezi). Frrat Üniversitesi Sosyal Bilimler Enst., Elâzı̆̆.

Cin, H. \& Akgündüz, A. (1990). Türk-İslam Hukuk Tarihi. İstanbul: Timaş Yayınları.

Çadırcı, M. (1997). Tanzimat Döneminde Anadolu Kentlerinin Sosyal ve Ekonomik Yapısı. Ankara: TTK Yayınları.

Daşcıoğlu, K. (2004). Osmanlı Devleti'nin Sürgün Siyaseti (XVIII. Yüzyıl) (Basılmamış Doktora Tezi). Süleyman Demirel Üniversitesi Sosyal Bilimler Enst., Isparta.

SEFAD, 2020; (43): 497-518 
Daşcığlu, K. (2010). Sürgün. Türk Diyanet Vakfı İslam Ansiklopedisi XXXVIII, TDV Yayınları, 167-169.

Erim, N. (1984). Osmanlı İmparatorluğu'nda kalebendlik cezası ve suçların sınıflandırılması üzerine bir deneme. Osmanlı Araştırmaları, (4), 79-88.

Gökçen, A. (1987). Tanzimat Dönemi Osmanlı Ceza Kanunları ve Bu Kanunlardaki Ceza Müeyyideleri (Basılmamış Yüksek Lisans Tezi). İstanbul Üniversitesi Sosyal Bilimler Enst., İstanbul.

Halaçoğlu, Y. (2014). XVIII. Yüzyılda Osmanlı İmparatorluğunda İskân Siyaseti ve Aşiretlerin Yerleştirilmesi. Ankara: TTK Yayınları.

İnalcık, H. (2008). Devlet-i Aliyye Osmanlı İmparatorluğu Üzerine Araştırmalar 1: Klasik Dönem (1302-1606). Ankara: Türkiye İş Bankası Kültür Yayınları.

Kaynar, R. (2010) Mustafa Reşit Paşa ve Tanzimat. Ankara: Türk Tarih Kurumu Basımevi.

Köksal, O. (2006). Osmanlı Hukuku'nda bir ceza olarak sürgün ve iki Osmanlı Sultanının sürgünle ilgili hatt-1 hümayunları. OTAM, (19), 283-341.

Öğün, T. (2010) Doğu'nun mirlerine son veda: Cizreli İzzeddin Şîr Bey ve isyanı. İstanbul: Yeditepe Yayınları.

Poyraz, Ö. (2017). Abdülmecid döneminde gayrimüslimlere verilen bireysel nefy (Sürgün) cezaları. (Ed.) Osman Köse, Geçmişten Günümüze Göç (I-E). Samsun: Canik Belediyesi Kültür Yayınları.

Sami, Ş. (1996). Kamus-i Türki, İstanbul: Çağrı Yayınları.

Taner, T. (1940), Tanzimat devrinde ceza hukuku, Tanzimat 1, İstanbul: Maarif Matbaası, 221232.

Taşbaş, E. (2012). Osmanlı İmparatorluğu'nda devlet görevlilerinin sürgün edilmesi: 19. Yüzyıl Kıbrıs Örneği. Mediterranean Journal of Humanities II, (1), 193-204.

Uluçay, M. Ç. (1951). Sürgünler yeni ve yakınçağlarda Manisa'ya ve Manisa'dan sürülenler. Belleten XV, (60), 507-591.

Uzunçarşıll, İ. H. (1965). Osmanlı Devleti'nin İlmiye Teşkilatı, Ankara: Türk Tarih Kurumu Basımevi.

Uzunçarşılı, İ. H. (1988). Osmanlı Devleti Merkez ve Bahriye Teşkilatı, Ankara: Türk Tarih Kurumu Basımevi.

Üçok, C.; Mumcu, A.; Bozkurt G. (2017) Türk Hukuk Tarihi, Ankara: Turhan Kitabevi.

Veldet, H. (1940). Kanunlaştırma hareketleri ve Tanzimat, Tanzimat 1, İstanbul: Maarif Matbaas1, 139-209.

Yurtseven, Y. (2001). Klasik dönem Osmanlı ceza hukukunda ta'zir suç ve cezaları. Selçuk Üniversitesi Hukuk Fakültesi Dergisi IX, (3-4), 265-292. 